\title{
Anthropogenic carbon dioxide in the South Atlantic western
}

\author{
basin \\ Aida F. Ríos ${ }^{*}$, Marcos Vázquez-Rodríguez¹, X. A. Padin¹, Fiz F. Pérez ${ }^{1}$ \\ ${ }^{1}$ Instituto de Investigaciones Marinas, CSIC, Eduardo Cabello 6, E-36208 Vigo, Spain \\ *Corresponding author. Email: aida@iim.csic.es. Tel.: +34 986231930 Ext. 371. Fax: +34 986292762
}

\section{Abstract}

The meridional WOCE line A17 was conducted during the austral summer of 1994 parallel to the eastern South American coast, from $55^{\circ} \mathrm{S}$ to $10^{\circ} \mathrm{S}$, where one of the main limbs of the North Atlantic Deep Water (NADW), i.e., the southward-flowing Deep Western Boundary Current (DWBC) is found. Full-depth profiles of $\mathrm{pH}$, total alkalinity and total inorganic carbon were measured and checked with analytical $\mathrm{CO}_{2}$ certified reference materials (CRMs), providing a high-quality dataset with good internal consistency for the $\mathrm{CO}_{2}$ system parameters that is well suited for anthropogenic $\mathrm{CO}_{2}\left(\mathrm{C}_{\mathrm{ANT}}\right)$ estimation. For the first time in the western Atlantic basin the $\mathrm{C}_{\mathrm{ANT}}$ has been calculated using four independent approaches and results are compared. The methods considered are the CFC-based TTD method and the $\varphi_{\mathrm{C}_{\mathrm{T}}}{ }^{\circ}$, TrOCA and $\Delta C^{*}$ carbon-system-based back-calculation methods. All four methods have produced $\mathrm{C}_{\mathrm{ANT}}$ distribution patterns that are in general good agreement: maximum concentrations of $\mathrm{C}_{\mathrm{ANT}}$ (50$\left.60 \mu \mathrm{mol} \mathrm{kg}{ }^{-1}\right)$ are predicted for the upper warm South Atlantic central waters from the tropical

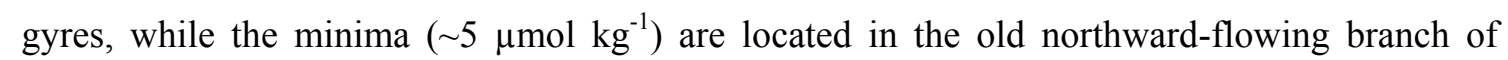
Circumpolar Deep Water. There are, however, some discrepancies detected. The TrOCA method yields the highest overall $\left[\mathrm{C}_{\mathrm{ANT}}\right]$ values, even over the theoretical limit of $\mathrm{C}_{\mathrm{ANT}}$ saturation for 1994 in the upper layers. The $\Delta C^{*}$ approach consistently yielded negative estimates of $\mathrm{C}_{\mathrm{ANT}}$ below $2800 \mathrm{dbar}$, even after correcting a reported $-8 \mu \mathrm{mol} \mathrm{\textrm {kg } ^ { - 1 }}$ bias in the alkalinity measurements of the WOCE A17 line. The main overall difference between the four methods corresponds to the relative $\mathrm{C}_{\mathrm{ANT}}$ maximum associated with the lower limb of NADW: this structure is well identified in the $\varphi \mathrm{C}_{\mathrm{T}}{ }^{\circ}$ and TTD methods but seems to disappear in the case of TrOCA and $\Delta C^{*}$. In agreement with other intercomparison studies of $\mathrm{C}_{\mathrm{ANT}}$, the specific inventories are significantly higher $(\sim 45 \%)$ than those reported in the GLODAP database obtained from the $\Delta C^{*}$ method. This suggests that the South Atlantic stores more $\mathrm{C}_{\mathrm{ANT}}$ than initially expected, particularly towards the southernmost tip of the WOCE A17 line, close to the Southern Ocean. The $\varphi \mathrm{C}_{\mathrm{T}}{ }^{\circ}$, TrOCA and TTD methods confirm an increasing tendency of $\mathrm{C}_{\mathrm{ANT}}$ specific inventories south from the Equator, while the $\Delta \mathrm{C}^{*}$ method shows a decreasing trend south from $35^{\circ} \mathrm{S}$. 


\section{Introduction}

The ocean plays a major role in the global carbon cycle by sequestrating annually 2.2 $\pm 0.4 \mathrm{Pg} \mathrm{C}$ out of the total $8.0 \pm 0.5 \mathrm{Pg} \mathrm{yr}^{-1}$ of anthropogenic $\mathrm{CO}_{2}\left(\mathrm{C}_{\mathrm{ANT}}\right)$ emitted to the atmosphere as a result of activities such as fossil fuel burning, land use changes, deforestation and cement production (Canadell et al., 2007). The Atlantic Ocean alone contributes with a share of $38 \%$ to the anthropogenic oceanic carbon storage, even though it only represents $29 \%$ of the global ocean surface area (Sabine et al., 2004). The formation of deep waters in the North Atlantic (NADW) and Southern Ocean (Antarctic Bottom Water; AABW) enhances significantly the Atlantic storage of $\mathrm{C}_{\mathrm{ANT}}$ (Lo Monaco et al., 2005). An important branch of the NADW, the Deep Western Boundary Current (DWBC), flows southwards from the Irminger and Labrador Seas and communicates with the South Atlantic basin through the Equatorial channel (Steinfeldt et al. 2007). The DWBC splits into eddies at $8^{\circ} \mathrm{S}$ such that, southwards from this latitude, the NADW is carried into the South Atlantic Ocean by migrating eddies, rather than by a continuous flow (Dengler et al., 2004). The eastward deflection of the southwardflowing DWBC has also been observed in the NADW domain (Weiss et al., 1985; Richardson and Schmitz, 1994; Rhein et al., 1995; Andrié, 1996; Mercier and Arhan, 1997; Arhan et al., 1998) along and just south of the Equator. On the other hand, model-based studies have suggested that a weakening in the thermohaline circulation and increases of sea surface temperature can potentially reduce ocean carbon uptake by up to $50 \%$ and that such reductions are only partly counterbalanced by changes in the marine biological cycle (Sarmiento and Le Quére, 1996; Sarmiento et al., 1998).

The Atlantic sector of the Southern Ocean withholds moderate concentrations of $\mathrm{C}_{\mathrm{ANT}}$ yet its massive volume turns it into one of the largest carbon reservoirs of this basin (VázquezRodríguez et al., 2009b). Manabe and Stouffer (1993) spotted from model results a potential modification of the ocean carbon sink in a vast region of the Southern Ocean, where increased rainfall would lead to surface freshening and increased stratification. The increased stratification 
reduces the downward flux of carbon and hinders the air-sea heat exchanges causing an overall decrease of the oceanic $\mathrm{C}_{\mathrm{ANT}}$ uptake in the Southern Ocean (Sarmiento et al. 1998). Recent estimates of $\mathrm{CO}_{2}$ sink in the Southern Ocean showed a weakening between 1981 and 2004 which was attributed to the observed increase in Southern Ocean winds resulting from human activities (Le Quére et al., 2007). The response of the carbon sink in the Southern Ocean to the changes in the wind stress is currently under debate (Böning et al., 2008). Most of the abovementioned results were obtained from model-based studies and, given the importance of the Southern Ocean in the context of global ocean carbon sink, the acquisition and analysis of highquality field data remain essential tasks to obtain the best possible $\mathrm{C}_{\mathrm{ANT}}$ estimates.

Over the years, a series of methods have been developed to retrieve the relatively small (3\%) $\mathrm{C}_{\mathrm{ANT}}$ signal from the large total inorganic carbon $\left(\mathrm{C}_{\mathrm{T}}\right)$ pool in the oceans. One of the issues concerning $\mathrm{C}_{\mathrm{ANT}}$ is that it cannot be measured directly. Consequently, the so-called backcalculation techniques were developed to estimate $\mathrm{C}_{\mathrm{ANT}}$ indirectly from direct observation of other tracers. This technique was first applied in the pioneering works of Brewer (1978) and Chen and Millero (1979). The methodology basis consists in separating from the measured $\mathrm{C}_{\mathrm{T}}$ the individual contributions or background signals from Organic Matter Remineralization (OMR) and dissolution of calcium carbonate species that had occurred since the water mass formed (it was last in contact with the atmosphere). Following the earlier concept of preformed nutrient defined by Redfield et al. (1963), the preformed total inorganic carbon $\left(\mathrm{C}_{\mathrm{T}}{ }^{\mathrm{o}}\right)$ was analogously defined $\left(\mathrm{C}_{\mathrm{T}}\right.$ of the water mass right after formation). This term and the air-sea $\mathrm{CO}_{2}$ disequilibrium $\left(\Delta \mathrm{C}_{\mathrm{dis}}\right)$ are also subtracted from the measured $\mathrm{C}_{\mathrm{T}}$. The $\mathrm{C}_{\mathrm{T}}{ }^{\circ}$ term has not remained constant after the pre-industrial era. The water masses have gradually formed in contact with a continuously altered atmosphere by human activity. Therefore, the $\mathrm{C}_{\mathrm{T}}{ }^{\circ}$ term tracks the imprint of $\mathrm{C}_{\mathrm{ANT}}$, which can be retrieved by subtracting a "zero- $\mathrm{C}_{\mathrm{ANT}}$ " reference from this preformed property. 

Ocean using an observational carbon-dependent back-calculation technique based on the one from Körtzinger et al. (1998) that had been applied in the North Atlantic. They found higher values (52-70 mol C m ${ }^{-2}$ ) than those computed from the $\Delta \mathrm{C}^{*}$ method (Gruber et al., 1996) (29$46 \mathrm{~mol} / \mathrm{m}^{2}$ ) at latitudes between $30-47^{\circ} \mathrm{S}$ in the Atlantic. Recently, a series of different $\mathrm{C}_{\mathrm{ANT}}$ methods like the TTD, TrOCA and $\varphi \mathrm{C}_{\mathrm{T}}{ }^{\circ}$ approaches (Waugh et al., 2006; Touratier et al., 2007; Vázquez-Rodríguez et al., 2009a) have confirmed Lo Monaco et al.'s (2005) findings and

The present work uses data from the WOCE A17 cruise, which runs parallel to the eastern South American coast, to obtain the $\mathrm{C}_{\mathrm{ANT}}$ distribution and inventories by applying a recent observational carbon-based approach, the $\varphi \mathrm{C}_{\mathrm{T}}{ }^{\circ}$ method (Vázquez-Rodríguez et al., 2009a) and the TrOCA method (Touratier et al., 2007). The obtained results are then compared with $\mathrm{C}_{\mathrm{ANT}}$ estimates from other back-calculation techniques, namely: the $\Delta \mathrm{C}^{*}$ (Gruber et al., 1996) and the CFC-based TTD approach (Waugh et al., 2006). This practice was never performed before in the western Atlantic basin.

\section{Dataset and methodology}

The measurements used in this work were performed onboard the R/V Maurice Ewing from January 4th until March 21st 1994 during the CITHER-2 / WOCE A17 cruise, framed within the WOCE/French Project CITHER (CIrculation THERmohaline). This quasi-meridional section was complemented by three short transverse lines to the continental slope at nominal latitudes $35^{\circ} \mathrm{S}, 13^{\circ} \mathrm{S}$, and $10^{\circ} \mathrm{N}$ (Fig. 1a). These transversal legs are not considered for the estimation of $\mathrm{C}_{\mathrm{ANT}}$ in the present study. The water samples were collected at 32 depth levels, from the surface down to $15 \mathrm{~m}$ above the bottom. The average horizontal spatial resolution of 30 nautical miles between stations was increased near the Equator and prior to stations that 
118 displayed steep bathymetric profiles. A general presentation of the cruise, and a thorough 119 description of the data used in this paper is provided in Groupe CITHER-2 (1995, 1996). Also, the quality-controlled database is publicly available

The $\mathrm{pH}$ measurements were originally reported in the NBS scale, as described in Pérez and Fraga (1987a). Total alkalinity $\left(\mathrm{A}_{\mathrm{T}}\right)$ measurements were performed every three stations using a single end point titration technique (Pérez and Fraga, 1987b; Mintrop et al., 2002). Total inorganic carbon $\left(\mathrm{C}_{\mathrm{T}}\right)$ was directly measured onboard with a coulometric method using a "Single Operator Multi-Parameter Metabolic Analyzer (SOMMA)" (Johnson et al., 1993). Where not measured, $\mathrm{C}_{\mathrm{T}}$ was calculated additionally from $\mathrm{A}_{\mathrm{T}}$ and $\mathrm{pH}_{\mathrm{NBS}}$ measurements using the thermodynamic equations of the carbon system and the $\mathrm{CO}_{2}$ dissociation constants from Dickson and Millero (1987; refit from Mehrbach et al. 1973). The measured and calculated $\mathrm{C}_{\mathrm{T}}$ values agreed within $\pm 1.6 \mu \mathrm{mol} \mathrm{kg}{ }^{-1}$ (Ríos et al., 2005). Additional physical-chemical properties used in the present work such as salinity, temperature, dissolved oxygen, nutrients and CFC-11 were measured using standard methodologies, which are detailed in the cited data reports. The accuracy of the measured $\mathrm{CO}_{2}$ parameters was evaluated using "Certified Reference Materials" (CRMs) supplied by Dr. A.G. Dickson (Univ. of California). The CRM samples were analyzed routinely for a total of $163 \mathrm{C}_{\mathrm{T}}$ measurements during the cruise, with an average difference from the certified $\mathrm{C}_{\mathrm{T}}$ value $\left(2115.15 \mu \mathrm{mol} \mathrm{\textrm {kg } ^ { - 1 }}\right)$ of $\pm 1.6 \mu \mathrm{mol} \mathrm{kg} \mathrm{kg}^{-1}$. The average of $146 \mathrm{CRM}$ analyses for $\mathrm{A}_{\mathrm{T}}$ was also in good agreement with the certified value to $\pm 1.7 \mu \mathrm{mol} \mathrm{\textrm {kg } ^ { - 1 }}$ (Ríos et al., 2005). An offset in the $A_{T}$ data of $-8 \mu \mathrm{mol} \mathrm{kg}^{-1}$ (i.e., $-0.32 \%$ ) was later detected for the WOCE A17 line and reported by Ríos et al. (2005). The nutrients were determined by segmented flow analysis with a Technicon II Autoanalyzer (Mouriño and Fraga,1985; AlvarezSalgado et al.,1992). The accuracy of nitrate and phosphate was \pm 0.1 and $\pm 0.01 \mu \mathrm{mol} \mathrm{kg}{ }^{-1}$, respectively. 
Regarding $\mathrm{C}_{\mathrm{ANT}}$ estimation, four methods have been considered in this study: the TTD (Waugh et al., 2006), $\Delta \mathrm{C}^{*}$ (Gruber et al., 1996), TrOCA (Touratier et al., 2007) and $\varphi \mathrm{C}_{\mathrm{T}}^{\mathrm{o}}$ (Vázquez-Rodríguez et al., 2009a,b). The $\Delta \mathrm{C}^{*}$ method was previously applied to the GLODAP dataset and results were accessed from the GLODAP website (http://cdiac.ornl.gov/oceans/glodap/Glodap_home.htm), as well as the CFC12-age data. The results of the $\mathrm{C}_{\mathrm{ANT}}$ estimates from the TTD method were downloaded from the following website: https://jshare.johnshopkins.edu/dwaugh1/public html/Cant/. On the basis of the variables needed to compute $\mathrm{C}_{\mathrm{ANT}}$, the methods here mentioned can be classified into two groups: a) the carbon-based methods $\left(\Delta \mathrm{C}^{*}, \operatorname{TrOCA}\right.$ and $\left.\varphi \mathrm{C}_{\mathrm{T}}{ }^{\circ}\right)$, which typically require measurements of $\mathrm{C}_{\mathrm{T}}, \mathrm{A}_{\mathrm{T}}$, oxygen, temperature, salinity and eventually some nutrient analysis. The reported $\mathrm{A}_{\mathrm{T}}$ offset of $-8 \mu \mathrm{mol} \mathrm{\textrm {kg } ^ { - 1 }}$ has been considered when calculating $\mathrm{C}_{\mathrm{ANT}}$ from backcalculation methodologies. In the case of the GLODAP- $\Delta \mathrm{C}^{*}$ results, the $-8 \mu \mathrm{mol} \mathrm{kg}^{-1} \mathrm{~A}_{\mathrm{T}}$ offset translates directly into a $4 \mu \mathrm{mol} \mathrm{kg}{ }^{-1} \mathrm{C}_{\mathrm{ANT}}$ offset (according to the formulation in Gruber et al., 1996), which has been added to the original GLODAP estimates of $\mathrm{C}_{\mathrm{ANT}}$; $b$ ) the TransientTracer-based methods (TTD) that commonly use CFC-11 or CFC-12 concentration measurements as proxies of the anthropogenic $\mathrm{CO}_{2}$ signal. The uncertainties in $\mathrm{C}_{\mathrm{ANT}}$ estimates for the $\Delta C^{*}, \operatorname{TrOCA}, \varphi \mathrm{C}_{\mathrm{T}}{ }^{\circ}$, and TTD methods are $\pm 7.9, \pm 6.2, \pm 5.2$, and $\pm 5.0, \mu \mathrm{mol} \mathrm{kg}^{-1}$, respectively. A summary of the $\mathrm{C}_{\mathrm{ANT}}$ methods used in this work can be found in VázquezRodríguez et al. (2009b).

The amount of dissolved $\mathrm{CaCO}_{3}(\Delta \mathrm{Ca})$ in the water column is one of the fundamental terms in $\mathrm{C}_{\mathrm{ANT}}$ back-calculation methodologies. The $\Delta \mathrm{Ca}$ is defined as $\Delta \mathrm{Ca}=1 / 2\left(\mathrm{PA}_{\mathrm{T}}-\mathrm{PA}_{\mathrm{T}}{ }^{\circ}\right)$ in terms of the measured $\mathrm{A}_{\mathrm{T}}$ and preformed $\mathrm{A}_{\mathrm{T}}\left(\mathrm{A}_{\mathrm{T}}{ }^{\circ}\right)$, i.e., the alkalinity of the considered water mass at the moment of formation, when it was last in contact with the atmosphere. The potential alkalinity term $\left(\mathrm{PA}_{\mathrm{T}}\right)$ is defined as $\mathrm{PA}_{\mathrm{T}}=\mathrm{A}_{\mathrm{T}}+\mathrm{NO}_{3}+\mathrm{PO}_{4}$ (Robertson et al., 1994). The OMR does not affect the $\mathrm{PA}_{\mathrm{T}}$ in the water column but carbonate shifts caused by $\mathrm{CaCO}_{3}$ dissolution still increase $\mathrm{PA}_{\mathrm{T}}$ by a factor of two. (Vázquez-Rodríguez et al., 2009a). A plot showing the 
vertical distribution of $\Delta \mathrm{Ca}$ along the WOCE A17 line is shown in Fig. 2. The corresponding $\mathrm{PA}_{\mathrm{T}}{ }^{\circ}$ term in the $\Delta \mathrm{Ca}$ expression was calculated as in Vázquez-Rodríguez et al. (2009a).

\section{Results}

The main water masses found on the WOCE A17 section are clearly identified from the temperature, salinity and silicate distributions (Figure 2). The warm and saline South Atlantic Central Water (SACW) is predominantly present above 1000 dbar along the whole section. There exist several varieties of this water mass that are well described in Mémery et al. (2000) (hereinafter M'00). The Antarctic Intermediate Water (AAIW) is characterised by its salinity minimum (34.1-34.5) that extends from the Subantarctic Front $\left(46^{\circ} \mathrm{S}\right)$ northwards, between 800 and 1000 dbar. Under the AAIW at $\sim 1000$ dbar and south from $20^{\circ} \mathrm{S}$ there is a relative maximum of temperature $\left(3.2{ }^{\circ} \mathrm{C}\right)$ and silicate $\left(45 \mu \mathrm{mol} \mathrm{kg}{ }^{-1}\right)$ corresponding to the upper Circumpolar Deep Water $(u \mathrm{CDW})$. The North Atlantic Deep Water (NADW) extends southwards along the section, characterised by an ample salinity maximum (>34.9) located between 1000 and 3500 dbar. Several varieties of NADW have also been thoroughly described in M'00, most importantly its upper and lower limbs ( $u$ NADW and $I N A D W$, respectively) that are identified in Fig. 2. In the Equatorial region at about 1800 dbar there is a relative salinity maximum $(\sim 34.95)$ associated to a minimum silicate signal $\left(\sim 20 \mu \mathrm{mol} \mathrm{kg}^{-1}\right)$ that identifies the uNADW branch. The INADW limb is located immediately below ( 3500 dbar), with slightly lower salinity and higher silicate values ( 34.90 and $35 \mu \mathrm{mol} \mathrm{kg}^{-1}$, respectively) than the upper branch. The maximum silicate values recorded are located at the southern end of the section. They are associated to the lower limb of the CDW (lCDW; $\left.\left[\mathrm{SiO}_{2}\right] \approx 120 \mu \mathrm{mol} \mathrm{kg}{ }^{-1}\right)$ and to the Antarctic Bottom Water (AABW) $\left(\left[\mathrm{SiO}_{2}\right]>125 \mu \mathrm{mol} \mathrm{kg}^{-1}\right.$ and $\left.\theta<0{ }^{\circ} \mathrm{C}\right)\left(\mathrm{M}^{\prime} 00\right)$. a measure of the OMR contribution to the measured $\mathrm{C}_{\mathrm{T}}$ signal. This term reaches values of up to 
$19985 \mu \mathrm{mol} \mathrm{kg}^{-1}$ in the case of AABW and has two relative minima $\left(\sim 49 \mu \mathrm{mol} \mathrm{kg}{ }^{-1}\right.$, when using the $200 \mathrm{R}_{\mathrm{C}}=1.45$ proposed by Anderson and Sarmiento, 1994) associated to the upper and lower NADW 201 limbs that evolve into a single relative AOU minima south from $20^{\circ} \mathrm{S}$ (Fig. 2; M'00). The stems from the relationship between the dissolution of opal and calcium carbonate. absolute AOU maximum is located at the core of the SACW, between 500 and 700 dbar north from $15^{\circ} \mathrm{S}$. This layer of the ocean accumulates high loads of organic matter from the Equatorial upwelling regions, and the $A O U / \mathrm{R}_{\mathrm{C}}$ term can amount up to $120 \mu \mathrm{mol} \mathrm{kg}{ }^{-1}$ of $\mathrm{C}_{\mathrm{T}}$. The lowest AOU values in the section correspond to young recently ventilated surface waters (lowest observed CFC12 age) around $40^{\circ} \mathrm{S}$ (M'00). Similarly, both limbs of NADW are characterised by their relative CFC12 age minima of $\sim 40$ yr. However, it must be noted that using CFC12 concentrations to infer water mass ages tends to underestimate ages in waters older than 25 years (Matear et al., 2003). In spite of the methodological biases, the waters found in the band between $40^{\circ} \mathrm{S}$ and the Equator and below $2000 \mathrm{db}$ are indeed very old water masses.

As introduced earlier, the dissolution of $\mathrm{CaCO}_{3}(\Delta \mathrm{Ca})$ also affects the $\mathrm{C}_{\mathrm{T}}$ content of a water parcel. The $\Delta \mathrm{Ca}$ is largest in the $\mathrm{AABW}$ and bottom waters in general throughout the section, where the oldest water masses are found (Chung et al., 2003). Although there is a general trend of $\Delta \mathrm{Ca}$ to increase with depth, an evident relative minimum of $\Delta \mathrm{Ca}\left(12 \mu \mathrm{mol} \mathrm{kg}{ }^{-1}\right)$ is observed associated to the moderately young $u$ NADW. These values are in contrast with the relative $\triangle \mathrm{Ca}$ maximum from the little-ventilated SACW/AAIW between 600 and $800 \mathrm{dbar}$, placed immediately above the $u$ NADW. Alternatively, the fairly good correlation between the observed $\Delta \mathrm{Ca}$ and silicate fields indicates that most dissolved $\mathrm{CaCO}_{3}$ is advected from Antarctic waters (namely, $\mathrm{AABW}$ and $\mathrm{CDW}$ ). This relationship is well documented in the literature (Broecker and Peng, 1982; Ríos et al., 1995; Pérez et al., 2002) and draws a clear line of demarcation between waters with strong Antarctic influence and the rest. The high correlation 

$60 \mu \mathrm{mol} \mathrm{kg}{ }^{-1}$, i.e., around the corresponding $C_{\mathrm{ANT}}^{\text {sat }}$ for 1994) are always found in the warm upper waters from the subtropical gyres (Fig. 3). In the $\mathrm{C}_{\mathrm{ANT}}$ distribution obtained with the $\varphi \mathrm{C}_{\mathrm{T}}{ }^{\mathrm{o}}$ method the minimum values $\left(\sim 5 \mu \mathrm{mol} \mathrm{kg}{ }^{-1}\right)$ are located at the oldest water masses (CFC12 age $\sim 50 \mathrm{yr})$ near the 3500 dbar level between the $u$ NADW and INADW, where the influence of lCDW is slightly more noticeable ( $\left.\mathrm{M}^{\prime} 00\right)$. Asides from this, there exists a relative minimum of $\mathrm{C}_{\mathrm{ANT}}$ at $1000 \mathrm{dbar}$ north of $15^{\circ} \mathrm{S}$. It coincides with the penetration northwards of $u \mathrm{CDW}$ (M'00), which erodes the relative maxima of the slightly more ventilated, younger, southward-flowing where the TTD approach has produced the highest $\mathrm{C}_{\mathrm{ANT}}$ estimates. $u N A D W$ and $I N A D W$. South from $30^{\circ} \mathrm{S}$, the high burdens of $\mathrm{C}_{\mathrm{ANT}}$ in subsurface waters reach down to 1200 dbar, while bottom waters show $\mathrm{C}_{\mathrm{ANT}}$ concentrations of approximately $10 \mu \mathrm{mol}$ $\mathrm{kg}^{-1}$. In the deepest end of the section, south of $40^{\circ} \mathrm{S}$, there is a slight increase of $\mathrm{C}_{\mathrm{ANT}}$ with respect to the surrounding waters that is likely caused by the penetration northwards of the AABW.

The $\mathrm{C}_{\mathrm{ANT}}$ estimates from the TTD approach do not depend on the measurements of carbon system parameters yet its results are in remarkable resemblance with the ones from the $\varphi \mathrm{C}_{\mathrm{T}}{ }^{\circ}$, most notably: the $\mathrm{C}_{\mathrm{ANT}}$ distributions at the subsurface, at the $u$ NADW and INADW associated maxima north of $15^{\circ} \mathrm{S}$, and the relative minima from the spreading of $u C D W, l C D W$ and the deep AABW. There are, however, discrepancies between the TTD and $\varphi \mathrm{C}_{\mathrm{T}}{ }^{\circ}$ results. Amongst the most relevant discrepancies there is the larger penetration of the high- $\mathrm{C}_{\mathrm{ANT}}$ from the uppermost layers waters down to $\sim 1200 \mathrm{dbar}$ uppermost layers south from $30^{\circ} \mathrm{S}$ predicted by the TTD, compared with the $\varphi \mathrm{C}_{\mathrm{T}}{ }^{\mathrm{o}}$ method. On the contrary, under $2000 \mathrm{dbar}$ the $\varphi \mathrm{C}_{\mathrm{T}}{ }^{\mathrm{o}}$ estimates are higher on average $\left(3 \pm 2 \mu \mathrm{mol} \mathrm{kg}{ }^{-1}\right)$ than the TTD ones, except in the case of the INADW 

al., 2004) were corrected by the $A_{T}$ offset (Ríos et al.,2005). Although this correction removes $23 \%$ of the negative values of $\mathrm{C}_{\mathrm{ANT}}$, the $\Delta \mathrm{C}^{*}$ method keeps showing negative $\mathrm{C}_{\mathrm{ANT}}$ concentrations below the 2800 dbar level in the WOCE A17 section (Fig. 3). These negative $\mathrm{C}_{\mathrm{ANT}}$ estimates were not considered for inventory calculations. Above this depth level the estimates are relatively similar to those from the $\varphi \mathrm{C}_{\mathrm{T}}{ }^{\mathrm{o}}$ method, reproducing the relative maximum associated to the $u \mathrm{NADW}$ north of $15^{\circ} \mathrm{S}$ and the relative minimum of the $u \mathrm{CDW}$. However, south from $30^{\circ} \mathrm{S}$ the layers with the largest concentrations of $\mathrm{C}_{\mathrm{ANT}}$ are thicker (by $\sim 250$ meters, likely due to the AAIW influence) than those predicted by the $\varphi \mathrm{C}_{\mathrm{T}}{ }^{\mathrm{o}}$ method (Fig. $3)$.

The TrOCA approach has the convenience of being a very straightforward $\mathrm{C}_{\mathrm{ANT}}$ method to apply, since it is based on one simple equation that can be applied to the global ocean. The obtained $\mathrm{C}_{\mathrm{ANT}}$ fields through this method follow the same general trends described above for the rest of methods. It reproduces well the $u \mathrm{CDW}$ relative minimum north of $15^{\circ} \mathrm{S}$ and the moderate $\mathrm{C}_{\mathrm{ANT}}$ values from the $\mathrm{AABW}$. The thickness of the high- $\mathrm{C}_{\mathrm{ANT}}$ upper layers is similar to that from the TTD and reaches deeper than in the case of the $\varphi C_{T}{ }^{\circ}$ and $\Delta C^{*}$ methods. Nonetheless, the TrOCA method has generally yielded the highest $\mathrm{C}_{\mathrm{ANT}}$ estimates. The absolute maximum $\mathrm{C}_{\mathrm{ANT}}$ values in the upper SACW are the highest of all four methods, reaching even over the theoretical upper-limit of $\mathrm{C}_{\mathrm{ANT}}^{\mathrm{sat}}$ for 1994 ( $\mathrm{C}_{\mathrm{ANT}}^{\mathrm{sat}}$ is the theoretical saturation concentration of $\mathrm{C}_{\mathrm{ANT}}$ for surface waters in equilibrium with the atmospheric $\mathrm{CO}_{2}$ levels when the cruise was conducted). The main differences with the other methodologies are found in the slightly higher values associated to the relative minimum of the lCDW and in the lower values $\left(\sim 5 \mu \mathrm{mol} \mathrm{kg}^{-1}\right)$ spreading between 3000 and 4000 dbar all along the section, especially with respect to the $\varphi C_{T}{ }^{\circ}$ and TTD methods. In addition, the relative maximum of the INADW predicted by the latter two methods disappears in the case of TrOCA, while the $\mathrm{C}_{\mathrm{ANT}}$ estimates for the $\mathrm{AABW}$ fall halfway 
in the range between the $\varphi \mathrm{C}_{\mathrm{T}}{ }^{\circ}$ and TTD results. Finally, the relative maximum in the $u$ NADW is also the highest of all four methods.

\section{Discussion}

One of the main goals in $\mathrm{C}_{\mathrm{ANT}}$ estimation is to be able to come up with an educated guess of how much of it is stored in the ocean. Since $\mathrm{C}_{\mathrm{ANT}}$ cannot be measured directly and there is no absolute reference against which results can be checked unequivocally, a comparison of the latitudinal variability (according to different estimation methodologies) of the specific $\mathrm{C}_{\mathrm{ANT}}$ inventories is well justified (Fig. 4).

The vertically integrated $\mathrm{C}_{\mathrm{ANT}}$ fields from the $\varphi \mathrm{C}_{\mathrm{T}}{ }^{\mathrm{o}}$ and TrOCA methods are found to be in outstanding agreement, always within the uncertainties of either method. It is remarkable to see such a concurrence given the different $\mathrm{C}_{\mathrm{ANT}}$ vertical gradients described by the two methods (Fig. 3). The observed differences stem mainly from the particular zero- $\mathrm{C}_{\mathrm{ANT}}$ references in each approach. The similarities between the $\varphi \mathrm{C}_{\mathrm{T}}{ }^{\mathrm{o}}$ and TrOCA specific inventories of $\mathrm{C}_{\mathrm{ANT}}$ likely comes from a compensation of $\mathrm{C}_{\mathrm{ANT}}$ between the uppermost and deeper layers: while the $\varphi \mathrm{C}_{\mathrm{T}}{ }^{\mathrm{o}}$ method predicts lower $\mathrm{C}_{\mathrm{ANT}}$ concentrations in the upper layers than TrOCA, the opposite occurs in deeper layers. When vertically integrated in the water column, the concentration values get, therefore, compensated. The lower surface concentrations in the $\varphi \mathrm{C}_{\mathrm{T}}{ }^{\mathrm{o}}$ approach derive from considering the temporal variability of the air-sea $\mathrm{CO}_{2}$ disequilibrium $\left(\Delta \Delta \mathrm{C}_{\mathrm{dis}}\right)$, compared to the TrOCA approach. On the other hand, the slightly higher bottom estimates of the $\varphi_{\mathrm{T}^{\circ}}{ }^{\mathrm{o}}$ method are the outcome of the $\mathrm{A}_{\mathrm{T}}{ }^{\circ}$ parameterization that was obtained taking subsurface layer observations as a reference of water mass formation conditions. 
The $\mathrm{C}_{\mathrm{ANT}}$ intercomparison work from Vázquez-Rodríguez et al. (2009b) included an analogous comparison for the $\varphi \mathrm{C}_{\mathrm{T}}{ }^{\circ}$ and TrOCA methods (amongst others) in the WOCE A14, which runs parallel to the west African coast along $10^{\circ} \mathrm{W}$ covering a similar latitudinal range to the WOCE A17. In that work, the specific inventories of $\mathrm{C}_{\mathrm{ANT}}$ calculated from the $\varphi \mathrm{C}_{\mathrm{T}}{ }^{\mathrm{o}}$ are higher than the ones from the TrOCA method south from $20^{\circ} \mathrm{S}$, unlike in the WOCE A17, where results are more alike. This discrepancy likely stems from the fact that, unlike in the present study, the TrOCA method showed large volumes of $\mathrm{C}_{\mathrm{ANT}}$-depleted waters in the deep South Atlantic region (south from $20^{\circ} \mathrm{S}$ ) of the WOCE A14 section. A recent publication (Yool et al., 2010) based on a comparison of $\mathrm{C}_{\mathrm{ANT}}$ estimates from the TrOCA method with model outputs questions the theoretical foundations of the TrOCA approach and reveals very large biases (up to $50 \%$ ) at regional level, suggesting that a satisfactory universal TrOCA parameterisation is not achievable.

The $\varphi \mathrm{C}_{\mathrm{T}}{ }^{\circ}$ and TrOCA methods give specific inventories of $\mathrm{C}_{\mathrm{ANT}}$ over the TTD ones, most notoriously in the latitudinal band between the Equator and $25^{\circ} \mathrm{S}$. This seems to be the direct result of the lower $\mathrm{C}_{\mathrm{ANT}}$ values predicted in this region by the TTD between 1000 and $2000 \mathrm{dbar}$ (Fig. 3), compared with the TrOCA and $\varphi \mathrm{C}_{\mathrm{T}}{ }^{\mathrm{o}}$ methods. Contrastingly, the opposite occurs with the high TTD values for the INADW. In spite of these discrepancies, the results obtained for the WOCE A14 in Vázquez-Rodríguez et al. (2009b) for the eastern Atlantic basin showed very similar specific inventories of $\mathrm{C}_{\mathrm{ANT}}$ for the TTD and $\varphi \mathrm{C}_{\mathrm{T}}{ }^{\mathrm{o}}$ methods. This is likely due to the fact that the deep waters in the eastern basin are older than those in the western one, and have therefore smaller amounts of $\mathrm{C}_{\mathrm{ANT}}$ and CFCs (Vázquez-Rodríguez et al., 2009b) that would yield lower methodological discrepancies. Regarding the difference of results here obtained for the WOCE A17 line, they are likely caused by the fact that the TTD approach assumes a globally constant mixing $(\Delta)$ to advection $(\Gamma)$ ratio $\Delta / \Gamma=1$ that might not be particularly representative of the ocean dynamics in the North Atlantic given the strong influence of the Meridional Overturning Circulation. Actually, it is most probable that the two NADW branches 
would not share the same $\Delta / \Gamma$ ratio since advection is likely to gain relevance over mixing in the upper NADW (uNADW) compared to the lower NADW (INADW) (Steinfeldt et al., 2009).

With respect to the inventory estimates from GLODAP- $\Delta \mathrm{C}^{*}$ the results are similar to the TTD ones north of $30^{\circ} \mathrm{S}$, mind the large amount of negative $\mathrm{C}_{\mathrm{ANT}}$ estimates in the $\Delta \mathrm{C}^{*}$ approach caused by the high zero- $\mathrm{C}_{\mathrm{ANT}}$ reference considered (Gruber et al., 1996; Matsumoto and Gruber, 2005). South of $30^{\circ} \mathrm{S}$ the $\Delta \mathrm{C}^{*}$ method also shows low specific inventories of $\mathrm{C}_{\mathrm{ANT}}$ (Fig. 4). Regarding these results, Lo Monaco et al. (2005) had already pointed out that the $\Delta C^{*}$ yielded close to zero or even negative $\mathrm{C}_{\mathrm{ANT}}$ values in $\mathrm{AABW}$, while the rest of methods predicted concentrations $\sim 10 \mu \mathrm{mol} \mathrm{kg}{ }^{-1}$. Compared with the specific inventories of $\mathrm{C}_{\mathrm{ANT}}$ in the WOCE A14 (Vázquez-Rodríguez et al., 2009b), the results here obtained are very alike: in the equatorial and subtropical regions of the western Atlantic basin the $\Delta \mathrm{C}^{*}$ and TTD methods predict very similar inventory values and trends, but this similarity ceases south from $40^{\circ} \mathrm{S}$, where the influence of Antarctic origin waters starts to be sizeable. The here-accounted alkalinity offset and the corresponding increase in $\mathrm{C}_{\mathrm{ANT}}$ specific inventory $\left(\sim 12 \mathrm{~mol} \mathrm{C} \mathrm{m}^{-2}\right)$ brings closer together the $\Delta C^{*}$ inventory and all others (differences reduce by $35 \%$, especially south of $40^{\circ} \mathrm{S}$ ) in Fig. 4. However, there are non-negligible remnant discrepancies, especially south of $35^{\circ} \mathrm{S}$, with the inventories from TTD, $\varphi \mathrm{C}_{\mathrm{T}}{ }^{\circ}$ and TrOCA.

Lee et al. (2003) provided $\mathrm{C}_{\mathrm{ANT}}$ inventories applying a slightly modified version of the $\Delta \mathrm{C}^{*}$ method and computed $\mathrm{C}_{\mathrm{ANT}}$ specific inventories by latitude bands separately for the eastern and western Atlantic basins. The western Atlantic $\mathrm{C}_{\mathrm{ANT}}$ inventories from Lee et al. (2003) (included in Fig. 4) are based on several cruises, including the WOCE A17. The basin wide inventories there described follow the same latitudinal trends as the WOCE A17 ones, except for the lower values south of $30^{\circ} \mathrm{S}$ when compared to the $\varphi \mathrm{C}_{\mathrm{T}}{ }^{\circ}$, TTD and TrOCA estimates. Part of these lower values south of $30^{\circ} \mathrm{S}$ (where only the section A17 was used to calculate inventories in 
Lee's work) can also be justified from the unaccounted $-8 \mu \mathrm{mol} \mathrm{kg}{ }^{-1}$ offset in $\mathrm{A}_{\mathrm{T}}$ data previously mentioned. On this regard, Ríos et al. (2003) had also described for the eastern Atlantic basin an increasing trend of $\mathrm{C}_{\mathrm{ANT}}$ inventories southwards from the Equator up to the Southern Ocean. They used a carbon-based back-calculation method for their $\mathrm{C}_{\mathrm{ANT}}$ estimates that yielded results in agreement with model outputs (Sarmiento et al., 1995). In addition to this reference, a set of different Ocean Global Circulation Models (Princeton/GFDL, MPI and Hadley OGCMs) have reproduced $\mathrm{C}_{\mathrm{ANT}}$ specific inventories showing similar trends of southward increment, i.e., an increase of $20-25 \mathrm{~mol} \mathrm{C} \mathrm{m}^{-2}$ from latitude $10^{\circ} \mathrm{S}$ to $50^{\circ} \mathrm{S}$ (Orr et al., 2001). The above evidences support the $\mathrm{C}_{\mathrm{ANT}}$ specific inventory results here obtained by the $\varphi \mathrm{C}_{\mathrm{T}}{ }^{\circ}$, TTD and $\operatorname{TrOCA}$ methods, especially south of $30^{\circ} \mathrm{S}$. This suggests revising the Atlantic and global $\mathrm{C}_{\mathrm{ANT}}$ inventories based on much larger, updated and high-quality data collections with different calculation methods.

On average, the western Atlantic basin shows $\mathrm{C}_{\mathrm{ANT}}$ specific inventories that are $\sim 35 \%$ larger than those in the eastern basin between the Equator and $45^{\circ} \mathrm{S}$, compared with the work from Vázquez-Rodríguez et al. (2009b). This is congruent with the fact that the deep waters of the West Atlantic basin, i.e., NADW and AABW, are more ventilated and therefore have higher $\mathrm{C}_{\mathrm{ANT}}$ burdens than those in the East Atlantic basin. As mentioned in the introductory section, the WOCE A17 tracks adequately the deep-water-bearing DWBC and facilitates making this interbasin comparison.

\section{Conclusions}

This work examines the $\mathrm{C}_{\mathrm{ANT}}$ distribution and inventories in the South Atlantic western basin calculated with data from the WOCE A17 cruise. The $\mathrm{C}_{\mathrm{ANT}}$ estimates obtained with the $\Delta \mathrm{C}^{*}, \varphi \mathrm{C}_{\mathrm{T}}{ }^{\circ}$, TrOCA (all three corrected for the $\mathrm{A}_{\mathrm{T}}$ offset reported in Ríos et al, 2005) and TTD methods show different concentration distributions depending on the water masses and 
circulation. All methods reported the maximum values of $\mathrm{C}_{\mathrm{ANT}}\left(50-60 \mu \mathrm{mol} \mathrm{kg} \mathrm{kg}^{-1}\right)$ in the upper warm waters from the tropical gyres, where the SACW predominates. The TrOCA method gives the highest $\left[\mathrm{C}_{\mathrm{ANT}}\right]$ values. In the upper layers, concentrations reach even over the theoretical limit of the $\mathrm{C}_{\mathrm{ANT}}$ saturation for 1994 . The minimum $\mathrm{C}_{\mathrm{ANT}}$ values $\left(\sim 5 \mu \mathrm{mol} \mathrm{kg}^{-1}\right)$ from all methods are found in the oldest waters flowing northwards, at about $1000 \mathrm{dbar}(u \mathrm{CDW})$ and around $3500 \mathrm{dbar}(I \mathrm{CDW})$. The TTD and $\varphi \mathrm{C}_{\mathrm{T}}{ }^{\circ}$ methods show similar distributions of these minimum values. The TrOCA and GLODAP- $\Delta \mathrm{C}^{*}$ methods both show the minima associated to the $u \mathrm{CDW}$, but the minimum associated to the $l \mathrm{CDW}$ reaches the bottom in the case of TrOCA (unlike the TTD and $\varphi \mathrm{C}_{\mathrm{T}}{ }^{\circ}$ methods) and it disappears in the case of the $\Delta \mathrm{C}^{*}$. North of $15^{\circ} \mathrm{S}$ the relative maxima are associated to the slightly more ventilated and younger $u$ NADW and INADW. The TrOCA approach gives the highest relative maximum in the $u$ NADW of all four methods, being three times higher than the TTD method and two times higher than $\Delta \mathrm{C}^{*}$ and $\varphi \mathrm{C}_{\mathrm{T}}{ }^{\mathrm{o}}$ methods. The main overall discrepancies between the four methods correspond to the relative $C_{A N T}$ maximum of the INADW: this structure is well identified in the $\varphi C_{T}{ }^{\circ}$ and TTD methods but seems to disappear in the case of TrOCA and GLODAP- $\Delta \mathrm{C}^{*}$. South of $40^{\circ} \mathrm{S}$ there is a slight increase of $\mathrm{C}_{\mathrm{ANT}}$ below 4000 dbar originated by the penetration northwards of the AABW that is detected by the $\varphi \mathrm{C}_{\mathrm{T}}{ }^{\circ}$, TrOCA and TTD methods. The $\Delta \mathrm{C}^{*}$ approach consistently yielded negative estimates of $\mathrm{C}_{\mathrm{ANT}}$ below $\sim 2800 \mathrm{db}$ (Fig. 3) that were not considered when computing column inventories of $\mathrm{C}_{\mathrm{ANT}}$.

In terms of specific inventories of the western Atlantic basin, the $\varphi \mathrm{C}_{\mathrm{T}}{ }^{\circ}, \operatorname{TrOCA}$ and TTD $\mathrm{C}_{\mathrm{ANT}}$ estimation methods confirm an increasing tendency south from the Equator. Contrarily, the $\Delta \mathrm{C}^{*}$ method shows a decreasing trend south from $35^{\circ} \mathrm{S}$. South of $40^{\circ} \mathrm{S}$ the average $\mathrm{C}_{\mathrm{ANT}}$ inventory obtained from $\varphi \mathrm{C}_{\mathrm{T}}{ }^{\circ}$, TrOCA and TTD methods is significantly higher $(\sim 45 \%)$ than those in the GLODAP database calculated from the $\Delta \mathrm{C}^{*}$ method. 


\section{ACKNOWLEDGEMENTS}

We would like to thank the captain, officers and crew of the R/V Maurice Ewing and all the participants of the CITHER-2 cruise. We are also very grateful to G. Rosón for his $\mathrm{pH}$ and alkalinity measurements. Special thanks go to M. Arhan (coordinator of the WOCE-France program CITHER) and L. Mémery (chief scientist of cruise CITHER-2). This work was developed and funded by the European Commission within the $6^{\text {th }}$ Framework Programme (EU FP6 CARBOOCAN Integrated Project, Contract no. 511176) and by the Xunta de Galicia within the INCITE framework (M4AO project PGIDIT07PXB402153PR). Marcos VázquezRodríguez was funded by the Consejo Superior de Investigaciones Científicas (CSIC) I3P predoctoral grant program REF.: I3P-BPD2005.

\section{References}

Alvarez-Salgado, X.A., Fraga, F., Pérez F.F., 1992. Determination of nutrient salts both in sea and brackish waters by automatic methods. The phosphate blank. Marine Chemistry 39, 311-319.

Anderson, L.A., Sarmiento J.L, 1994. Redfield ratios of remineralization determined by nutrient data analysis, Global Biogeochemical Cycles 8, 65-80.

Arhan, M. , Mercier, H., Bourlès, B., Gouriou, Y., 1998. Hydrographic sections across the Atlantic at $7^{\circ} 30 \mathrm{~N}$ and $4^{\circ} 30$ S. Deep-Sea Res. Part I 45, 829-872.

Böning, C.W., Dispert, A., Visbeck, M., Rintoul, S.R., Schwarzkopf, F.U., 2008. The response of the Antarctic Circumpolar Current to recent climate change. Nature Geoscience 1, 864-869.

Brewer, P., 1978. Direct observation of the oceanic $\mathrm{CO}_{2}$ increase. Geophysical Research. Letters 5, 997-1000.

Broecker, W.S., Peng, T.-H., 1982, Tracers in the Sea. Columbia University. Eldigio Press. New York, $690 \mathrm{pp}$.

Canadell, J., Le Quéré, C., Raupach, M. R. , Fields C., et al., 2007. Contributions to accelerating atmospheric $\mathrm{CO}_{2}$ growth from economic activity, carbon intensity, and efficiency of natural sinks. Proceedings of National Academy Sciences 104(47), 18866-18870, doi:10.1073/ pnas.0702737104. vol. 104 no. 47

Chen, C.T., Millero, F.J., 1979. Gradual increase of oceanic carbon dioxide. Nature 277, 205206.

Chung, S.-N., Lee, K., Feely, R. A., Sabine, C. L., Millero, F. J., Wanninkhof, R., Bullister, J. L., Key, R. M., and Peng, T.-H., 2003, Calcium carbonate budget in the Atlantic Ocean based on water column inorganic carbon chemistry, Global Biogeochem. Cycles, 17(4), 1093, doi:10.1029/2002GB002001.

Dengler, M., Schott, F.A., Eden, C., Brandt, P., Fischer, J., Zantopp, R.J., 2004. Break-up of the Atlantic deep western boundary current into eddies at $8^{\circ} \mathrm{S}$. Nature 432, 1018-1020.

Dickson, A.G., Millero, F.J., 1987. A comparison of the equilibrium constants for the dissociation of carbonic acid in seawater media, Deep Sea Research I 34, 1733-1743. 
Groupe CITHER-2, Le, 1995. Recueil de données, campagne CITHER-2, R/V Maurice Ewing (4 janvier-21 mars 1994). Volume 2: CTD-O2. Rapport Interne LPO 95-04, 520 pp.

Groupe CITHER-2, Le, 1996. Recueil de données, campagne CITHER-2, R/V Maurice Ewing (4 janvier-21 mars 1994). Volume 1: Mesure 'en route', parameters méthéorologiques, bathymetrie et courantométrie Doppler. Rapport Interne LPO 96-01, 180p.

Gruber, N., Sarmiento, J.L, Stocker. T.F., 1996. An improved method for detecting anthropogenic $\mathrm{CO}_{2}$ in the oceans. Global Biogeochemical Cycles 10, 809-837.

Johnson, K.M., Wills, K.D., Butler, D.B., Johnson, W.K., Wong C.S., 1993. Coulometric total carbon dioxide analysis for marine studies: maximizing the performance of an automated gas extraction system and coulometric detector. Marine Chemistry 17, 1-21.

Key, R.M., Kozyr, A., Sabine, C.L., Lee, K., Wanninkhof, R., et a., 2004. A global ocean carbon climatology: Results from Global Data Analysis Project (GLODAP). Global Biogeochemical Cycles 18, GB4031, doi:10.1029/2004GB002247.

Körtzinger, A., Mintrop, L., Duinker, J.C., 1998. On the penetration of anthropogenic $\mathrm{CO}_{2}$ into the North Atlantic ocean. Journal of Geophysical Research 103, 18681-18689.

LeQuéré C., Rödenbeck, C., Buitenhuis, E.T., Conway, T.J., et al., 2008. Saturation of the Southern Ocean $\mathrm{CO}_{2}$ Sink Due to Recent Climate Change. Science 316, 1735-1738.

Lee, K., Choi, S.-D. Park, G.-H. Wanninkhof, R., et al.. 2003. An updated anthropogenic $\mathrm{CO}_{2}$ inventory in the Atlantic Ocean. Global Biogeochemical Cycles 17 (4), 1116, doi: 10.1029/2003GB002067.

Lo Monaco, C., Goyet, C., Metzl, N., Poisson, A., Touratier, F., 2005. Distribution and inventory of anthropogenic $\mathrm{CO}_{2}$ in the Southern Ocean: Comparison of three data-based methods. J. Geophys. Res. 110, C09S02, doi:10.1029/2004JC002571.

Manabe, S., Stouffer. R., 1993. Century-scale effects of increased atmospheric $\mathrm{CO}_{2}$ on the ocean-atmosphere system, Nature 364, 215-218

Matear, R.J., Wong, C.S., Xie, L., 2003. Can CFCs be used to determine anthropogenic $\mathrm{CO}_{2}$ ? Global Biogeochem. Cycles 17, doi:10.1029/2001GB001415.

Matsumoto, K., Gruber. N., 2005. How accurate is the estimation of anthropogenic carbon in the ocean? An evaluation of the $\Delta C^{*}$ method. Global Biogeochemical Cycles 19, doi: 10.1029/2004GB002397.

Mehrbach, C., Culberson, C.H., Hawley, J.E., Pytkowicz, R.M., 1973, Measurements of the apparent dissociation constant of carbonic acid in seawater at atmospheric pressure. Limnology and Oceanography 8, 897-907.

Mémery, L., Arhan, M., Álvarez-Salgado, X.A., Messias, M.-J., et al., 2000. The water masses along the western boundary of the south and equatorial Atlantic, Progress in Oceanography 47, 69-98.

Mercier, H.,M. Arhan, 1997. Two meridional hydrographic sections in the eastern South Atlantic Ocean (WHP lines A13 and A14), Intl. WOCE Newsl. 28, 28-30.

Mintrop, L., Pérez, F.F., Gonzalez-Dávila, M., Santana-Casiano, M.J., Kortzinger, A., 2002. Alkalinity determination by potentiometry: Intercalibration using three different methods. Ciencias Marinas 26(1), 23-37.

Mouriño, C., Fraga, F., 1985. Determinacion de nitratos en agua de mar. Investigacion Pesquera 49, 81-96.

Orr, J.E., Maier-Reimer, E., Mikolajewicz, U., Monfray, P., et al., 2001. Estimates of anthropogenic carbon uptake from four three-dimensional global ocean models, Global Biogeochemical Cycles 15 (1), 43-60.

Pérez, F.F., Álvarez, M., Ríos, A.F., 2002, Improvements on the back-calculation technique for estimating anthropogenic $\mathrm{CO}_{2}$. Deep-Sea Res. I 49, 859-875.

Pérez, F.F., Fraga, F., 1987a. The pH measurements in seawater on NBS scale. Marine Chemistry $21,315-327$.

Pérez, F.F., Fraga, F., 1987b. A precise and rapid analytical procedure for alkalinity determination. Marine Chemistry 21, 169-182.

Redfield, A. C., Ketchum,, B. H., Richards, F. A.,1963. The influence of organisms on the composition of sea-water. The Sea 2, 26-77. 
Ríos, A.F., Alvarez-Salgado, X.A., Pérez, F.F., Bingler L.S., Arístegui, J. Mémery, L., 2003. Carbon dioxide along WOCE line A14: Water masses characterization and anthropogenic entry. Journal Geophysical Research 108(C4), 3123, doi:10.1029/2000JC000366.

Ríos, A.F., Anderson, T.R., Pérez, F.F., 1995, The carbonic system distribution and fluxes in the NE Atlantic during Spring 1991, Prog. Oceanog. 35, 295-314.

Ríos, A.F., Johnson, K.M., Álvarez-Salgado, X.A., et al., 2005. Carbon dioxide, hydrographic, and chemical data obtained during The R/V Maurice Ewing Cruise in the South Atlantic Ocean (WOCE Section A17, 4 January - 21 March 1994), Carbon Dioxide Information Analysis Center, Oak Ridge National Laboratory, ORNL/CDIAC- 148, NDP-084, 1-27.

Robertson, J.E., Robinson, C., Turner, D.R., Holligan, P., et al., 1994. The impact of a coccolithophore bloom on oceanic carbon uptake in the northeast Atlantic during summer 1991. Deep-Sea Research I 41, 297-314.

Sabine C.L., Feely, R.A., Gruber, N., Key, R.M. et al., 2004. The oceanic sink for anthropogenic $\mathrm{CO}_{2}$. Science 305, 367-371.

Sarmiento, J.L., Le Quéré, C., 1996. Oceanic carbon dioxide uptake in a model of century-scale global warming, Science 274, 1346-1350,

Sarmiento, J.L., Murnane, R., Le Quere C., 1995. Air-sea $\mathrm{CO}_{2}$ transfer and the carbon budget of the North Atlantic, Phil. Trans. R. Soc. London 348, 211-219.

Sarmiento, J.L., Hughes, T.M.C., Stouffer, R.J., Manabe, S., 1998. Simulated response of the ocean carbon cycle to anthropogenic climate warming, Nature 393, 245-249,

Steinfeldt, R., Rhein, M., Walter, M., 2007. NADW transformation at the western boundary between $66^{\circ} \mathrm{W}-20^{\circ} \mathrm{N}$ and $60^{\circ} \mathrm{W}-10^{\circ} \mathrm{N}$. Deep-Sea Research I 54, 835-855.

Steinfeldt, R., Rhein, M., Bullister, J.L., Tanhua T., 2009. Inventory changes in anthropogenic carbon from 1997-2003 in the Atlantic Ocean between $20^{\circ} \mathrm{S}$ and $65^{\circ} \mathrm{N}$, Global Biogeochemical Cycles 23, doi:10.1029/2008GB003311.

Touratier, F., Azouzi, L., Goyet, C., 2007. CFC-11, $\Delta 14 \mathrm{C}$ and $3 \mathrm{H}$ tracers as a means to assess anthropogenic $\mathrm{CO}_{2}$ concentrations in the ocean. Tellus 59B, 318-325, doi: 10.1111/j.1600-0889.2006.00247.x.

Vázquez-Rodríguez, M., Padin, X.A., Ríos, A.F., Bellerby, R.G.J., Pérez, F.F., 2009a. An upgraded carbon-based method to estimate the anthropogenic fraction of dissolved $\mathrm{CO}_{2}$ in the Atlantic Ocean. Biogeosciences Discuss. 6, 4527-4571.

Vázquez-Rodríguez, M., Touratier, F., Lo Monaco, C., Waugh, D.W., Padin, X.A., et al., 2009b. Anthropogenic carbon distributions in the Atlantic Ocean: Databased estimates from the Arctic to the Antarctic, Biogeosciences 6, 439-451.

Waugh, D.W., Hall, T.M., McNeil, B.I., Key, R., Matear, R.J., 2006. Anthropogenic $\mathrm{CO}_{2}$ in the oceans estimated using transit time distributions, Tellus, 58B, 376-389, DOI: 10.1111/j.1600-0889.2006.00222.x.

Weiss, R.F., Bullister, J.L., Gammon, R.H. Warner, M.J., 1985. Atmospheric chlorofluoromethanes in the deep equatorial Atlantic. Nature 314, 608-610.

Yool, A., Oschlies, A., Nurser, A.J.G., Gruber, N., 2010. A model-based assessment of the TrOCA approach for estimating anthropogenic carbon in the ocean, Biogeosciences 7, $723-751$.

Figure captions

Figure 1 Map of the eastern South Atlantic Ocean showing the position of the 107 fulldepth stations surveyed during the CITHER-2 (WOCE A17) cruise. 
Figure 2 Vertical profiles of measured $\theta\left({ }^{\circ} \mathrm{C}\right)$, salinity, $\left[\mathrm{Si}(\mathrm{OH})_{4}\right]\left(\mu \mathrm{mol} \mathrm{kg}{ }^{-1}\right)$, calculated Apparent Oxygen Utilisation (AOU; $\left.\mu \mathrm{mol} \mathrm{kg}{ }^{-1}\right), \mathrm{CaCO}_{3}$ dissolution $(\Delta \mathrm{Ca} ; \mu \mathrm{mol}$ $\mathrm{kg}^{-1}$ ) and water mass age (years) from CFC12 data. The acronyms of the main water masses present along the WOCE A17 line are labeled on the $\theta$ (SACW, $u \mathrm{NADW}, I \mathrm{NADW}, u \mathrm{CDW}, I \mathrm{CDW}$ and $\mathrm{AABW}$ ) and salinity (AAIW) plots.

Figure 3 Vertical profiles of $\mathrm{C}_{\mathrm{ANT}}$ along the WOCE A17 line according to four different estimation approaches: the $\varphi \mathrm{C}_{\mathrm{T}}{ }^{\circ}$, the GLODAP- $\Delta \mathrm{C}^{*}$, the TrOCA and the TTD methods. All concentrations are in $\mu \mathrm{mol} \mathrm{kg}{ }^{-1}$. The reported $-8 \mu \mathrm{mol} \mathrm{kg}{ }^{-1} \mathrm{~A}_{\mathrm{T}}$ offset (Ríos et al., 2005) has been considered and corrected for in all three $\mathrm{C}_{\mathrm{ANT}}$ backcalculation approaches, i.e., $\varphi \mathrm{C}_{\mathrm{T}}{ }^{\circ}$, GLODAP- $\Delta \mathrm{C}^{*}$ and TrOCA. The spots where negative $\mathrm{C}_{\mathrm{ANT}}$ estimates were predicted by the $\Delta \mathrm{C}^{*}$ method have been automatically set to zero and filled with a light purple color. They are located below the $\mathrm{C}_{\mathrm{ANT}}=0$ isopleth (pressures $>\sim 2800$ dbar).

Figure $4 \mathrm{C}_{\mathrm{ANT}}$ specific inventories were estimated by vertical integration. The uncertainties of these estimates were calculated by means of random propagation with depth of an average $5.2 \mu \mathrm{mol} \mathrm{kg}^{-1}$ standard error of the $\mathrm{C}_{\mathrm{ANT}}$ estimate over 100 perturbation iterations. Assuming that the uncertainties attached to the $\mathrm{C}_{\mathrm{ANT}}$ estimation method are purely random and do not introduce biases, the final error is calculated by propagating the individual errors associated to the samples. They reflect both measurement and parameterization errors. For each of the considered latitude belts the mean of the integrated values at each station was calculated. The error bars here shown were computed as the confidence intervals of the mean. 
Figure 1

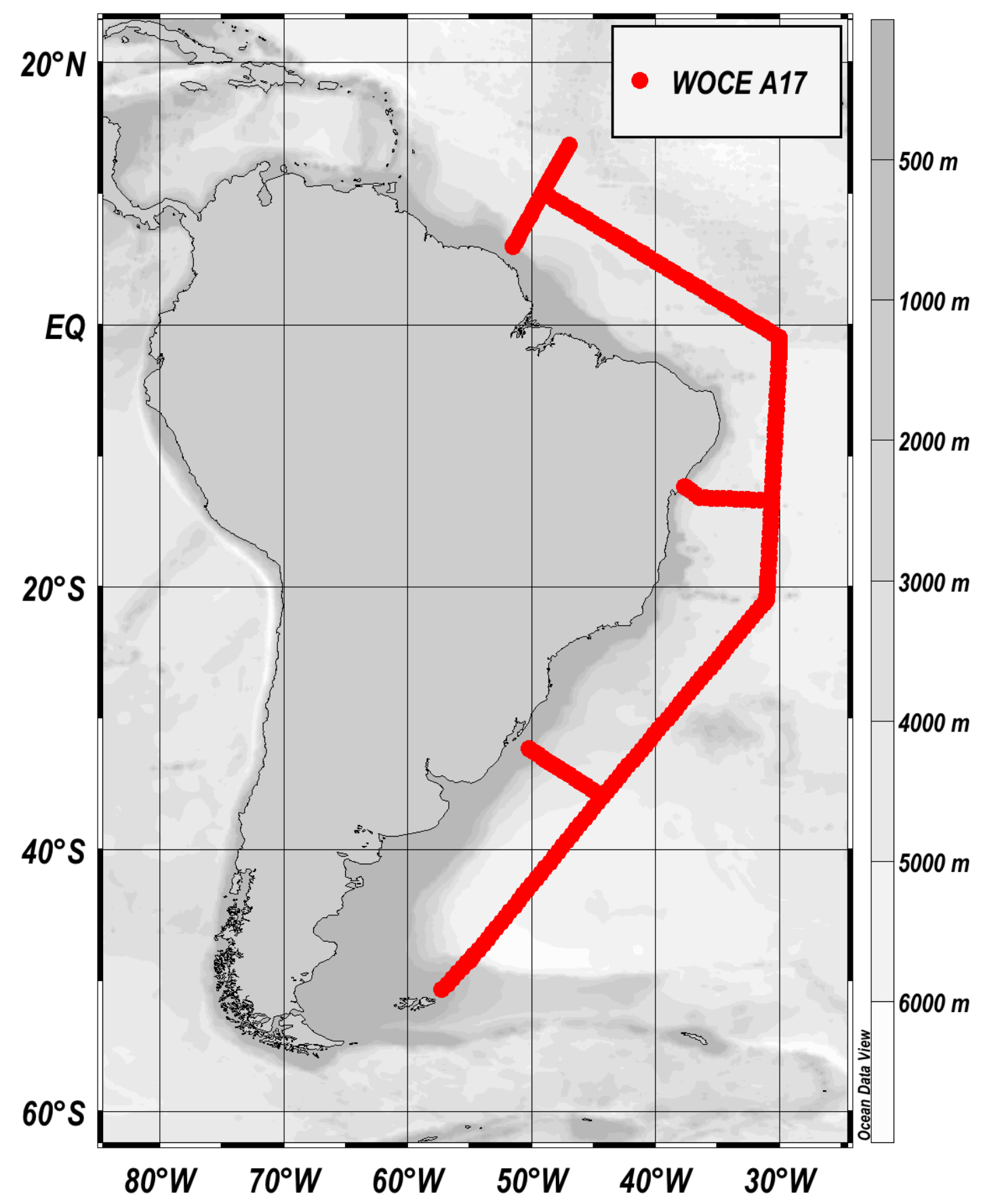


Figure 2
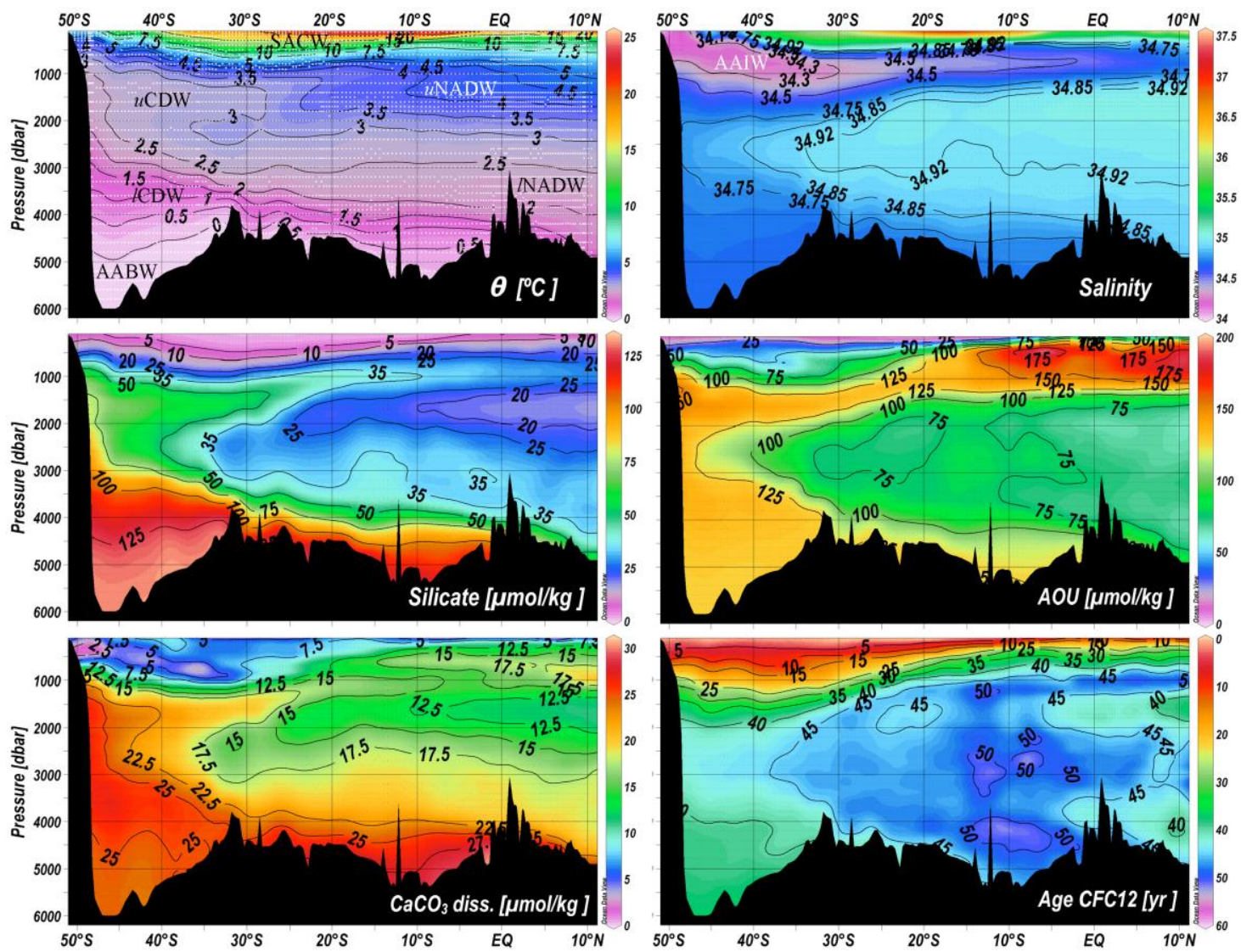
Figure 3

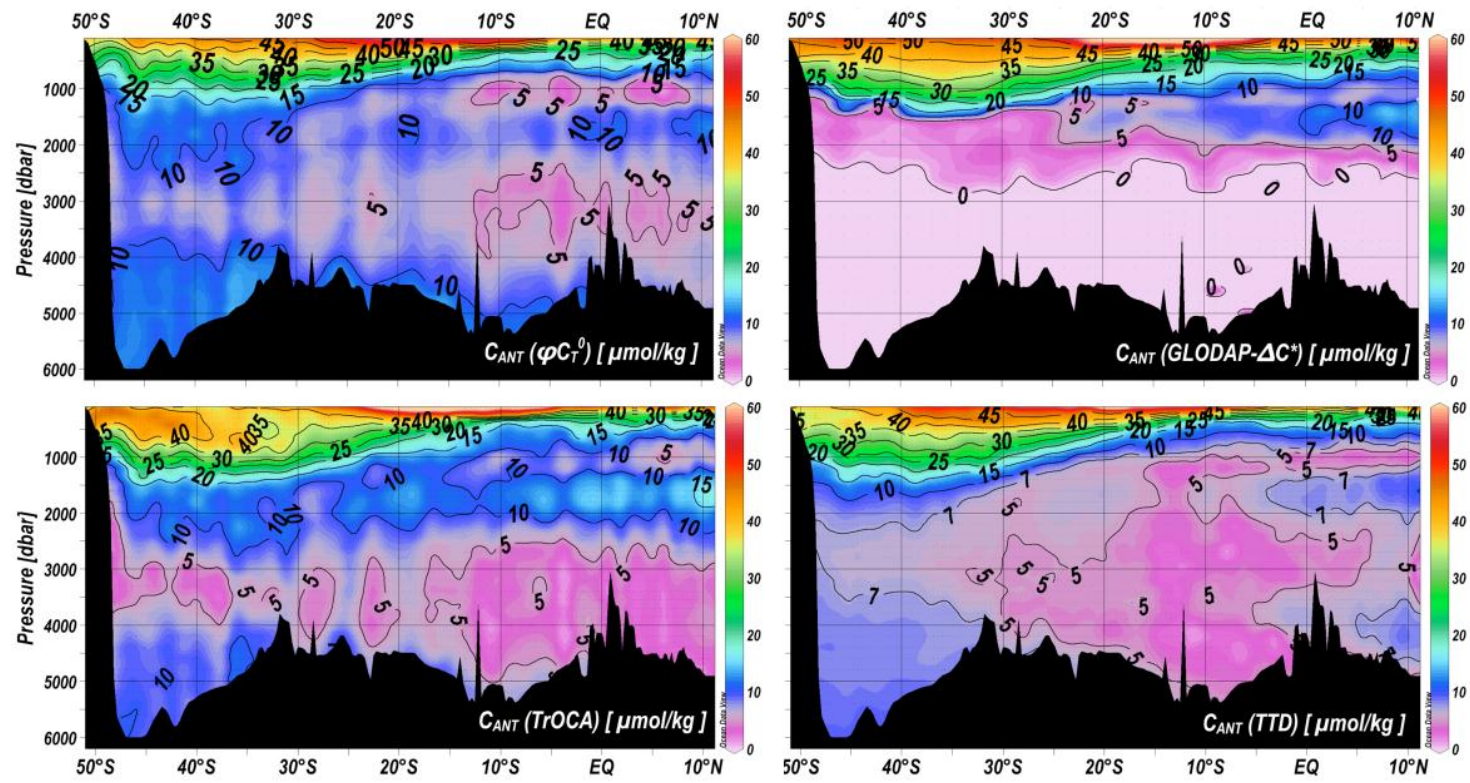


Figure 4

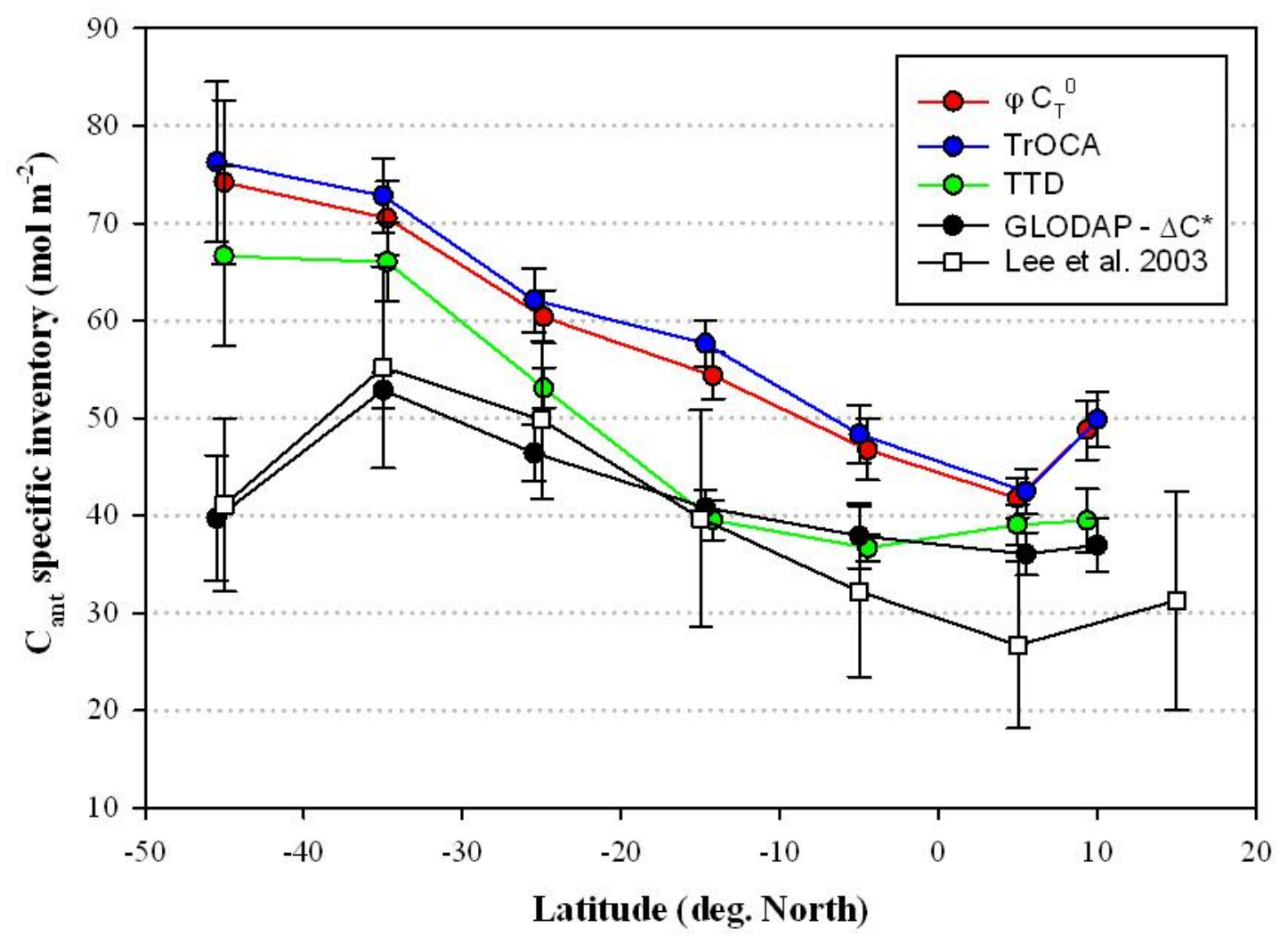

